\title{
Bacillus vallismortis sp. nov., a Close Relative of Bacillus subtilis, Isolated from Soil in Death Valley, California
}

\author{
MICHAEL S. ROBERTS, ${ }^{1 *}$ L. K. NAKAMURA, ${ }^{2}$ AND FREDERICK M. COHAN ${ }^{3}$ \\ Center for Microbial Ecology, Michigan State University, East Lansing, Michigan 48824-1101'; Microbial Properties Research, \\ National Center for Agricultural Utilization Research, Agricultural Research Service, U.S. Department of Agriculture, \\ Peoria, Illinois 61604'2; and Department of Biology, Wesleyan University, Middletown, Connecticut 06459-0170 3
}

\begin{abstract}
Five Bacillus strains isolated from Death Valley soil were shown to belong to a previously unidentified species, for which we propose the name Bacillus vallismortis. The type strain is strain DV1-F-3 (= NRRL B-14890). On the basis of previously published restriction digestion data, $B$. vallismortis is most closely related to Bacillus subtilis. At this time B. vallismortis can be distinguished from $B$. subtilis only by differences in whole-cell fatty acid compositions, DNA sequences, and levels of reassociation of genomic DNA.
\end{abstract}

The species most closely related to Bacillus subtilis are easily distinguished by differences in their DNA sequences. $B$. subtilis, Bacillus mojavensis, Bacillus atrophaeus, Bacillus amyloliquefaciens, and Bacillus licheniformis can be distinguished by genomic hybridization data $(11,12,16)$; these species form distinct DNA sequence clusters for shared genes $(15,16)$, and as a result of sequence divergence, levels of transformation among these species are low $(14,16,21)$. However, the sequence differences among these species are accompanied by very few phenotypic differences. $B$. subtilis can be distinguished phenotypically from $B$. mojavensis only by its fatty acid composition (16) and from $B$. atrophaeus only by its pigmentation (12). B. subtilis can be distinguished from B. amyloliquefaciens by only three phenotypic traits $(9,11)$ and from the more distantly related organism $B$. licheniformis by only five phenotypic traits (9). The dearth of diagnostic phenotypic characteristics in this group suggests there may be species which are closely related to $B$. subtilis that have not been discovered yet (16). Indeed, two close relatives of $B$. subtilis ( $B$. atrophaeus and $B$. mojavensis) have been discovered in only the last 6 years $(12,16)$.

A recent survey of genetic variation among soil isolates having $B$. subtilis-like phenotypes revealed an unexpected cluster of strains very closely related to $B$. subtilis (15). On the basis of the results of a restriction digestion analysis of the gyr $A$, $p o l C$, and $r p o B$ genes, a cluster of five strains obtained from Death Valley formed a monophyletic group that was most closely related to $B$. subtilis (Fig. 1). In this paper we present evidence that these Death Valley group strains are members of a previously unidentified Bacillus species.

\section{MATERIALS AND METHODS}

Bacterial strains. The five strains previously identified as members of the Death Valley group (15) are listed in Table 1. These strains were isolated from soil obtained at four collection sites in Death Valley (15). A prototrophic rifampin-susceptible derivative of $B$, subtilis 168 , designated strain $1 \mathrm{~A} 2$ (= NRRL B-14819), was obtained from the Bacillus Genetic Stock Center. The Agricultural Research Service Culture Collection at the National Center for Agricultural Utilization Research provided the following type strains: $B$. amyloliquefaciens NRRL B-14393 (= ATCC 23350), B. atrophaeus NRRL NRS213, Bacillus lentimorbus NRRL B-2522 (= ATCC 14707), B. licheniformis NRRL NRS-1264 (= ATCC 14580), B. mojavensis NRRL B-14698, Bacillus popilliae NRRL B-2309 (= ATCC 14706), and B. subtilis NRRL NRS-744 (= ATCC 6051). (The prefix NRRL indicates that a strain is maintained in the Agricultural Research Service Culture Collection; each NRRL designation in-

* Corresponding author. Phone: (517) 432-3771. Fax: (517) 4323770. Electronic mail address: robert62@pilot.msu.edu. cludes the prefix B-, which identifies organisms that were obtained directly from individuals or were isolated at the National Center for Agricultural Utilization Research, or the prefix NRS-, which identifies strains obtained from the N. R. Smith Bacillus collection.)

Selection for spontaneous rifampin-resistant mutants. We obtained rifampinresistant ( Rif $^{\text {; }}$, encoded by $r p o B$ ) mutants of each strain (which were used as donors in transformation experiments) by using previously described methods (16).

Purification of genomic DNA. For DNA preparation, the type strains of $B$. popilliae and $B$. lentimorbus were cultured in $\mathrm{J}$ medium by using the protocol of Gordon et al. (6); all other strains were cultured in brain heart infusion medium (Difco). Genomic DNA for use in transformation experiments was obtained from a spontaneous $\mathrm{Rif}^{\mathrm{T}}$ mutant of each donor strain, as described previously (3). The procedure used to prepare highly purified DNA for reassociation experiments has been described previously (13).

Transformation. Using the protocol of Cohan et al. (3), we induced strains to become competent for transformation in liquid cultures. Each strain was then transformed to rifampin resistance with genomic DNA from its own Rif ${ }^{\mathrm{T}}$ mutant (homogamic transformation) and with DNAs from Rif $^{\top}$ mutants of other strains (heterogamic transformation). We calculated transformation frequencies by determining the fraction of cells from each recipient culture that were transformed to rifampin resistance, after we corrected for mutation. Sexual isolation (i.e., resistance to transformation) between a recipient and a test donor was quantified by determining the ratio of the frequency of homogamic transformation to the frequency of heterogamic transformation $(14,21)$.

DNA-DNA reassociation and $\mathbf{G}+\mathbf{C}$ content determinations. The renaturation rates of genomic fragments from pairs of strains were determined spectrophotometrically with a model 250 UV spectrophotometer (Gilford Systems, CIBACorning Diagnostics Corp., Oberlin, Ohio) equipped with a model 2527 thermoprogrammer (13). The equation of De Ley et al. (4) was used to calculate the extent of DNA-DNA reassociation.

The $\mathrm{G}+\mathrm{C}$ content was estimated by the thermal melting procedure described by Mandel and Marmur (10). Escherichia coli DNA with a G $+\mathrm{C}$ content of 51 mol\% was used for comparison.

Phenotypic characterization. Physiological, morphological, and metabolic characteristics (except fatty acid composition) were determined as described previously $(6,13)$. The whole-cell fatty acid composition was determined by using the MIDI system of Sasser (18) and organisms that had been grown for $24 \mathrm{~h}$ at $28^{\circ} \mathrm{C}$ on Trypticase soy agar. We determined the fatty acid compositions of the five members of the Death Valley group and compared these compositions with data for related species obtained previously (16). B. lentimorbus and B. popilliae were not characterized because their phenotypes were known to be very different from the phenotypes of $B$. subtilis-like organisms (2).

\section{RESULTS}

Sexual isolation between the Death Valley group and $B$. subtilis. Each Death Valley group strain failed to show any evidence of transformation toward rifampin resistance, whether the donor DNA was from the recipient's own Rifr mutant or from a Rif $^{\mathrm{T}}$ mutant of $B$. subtilis $1 \mathrm{~A} 2$; that is, the frequency of appearance of rifampin-resistant colonies when donor DNA was added was about the same as the frequency of appearance under mutation alone (data not shown). Because of this apparent lack of competence in the Death Valley group strains, sexual isolation between the Death Valley group and 


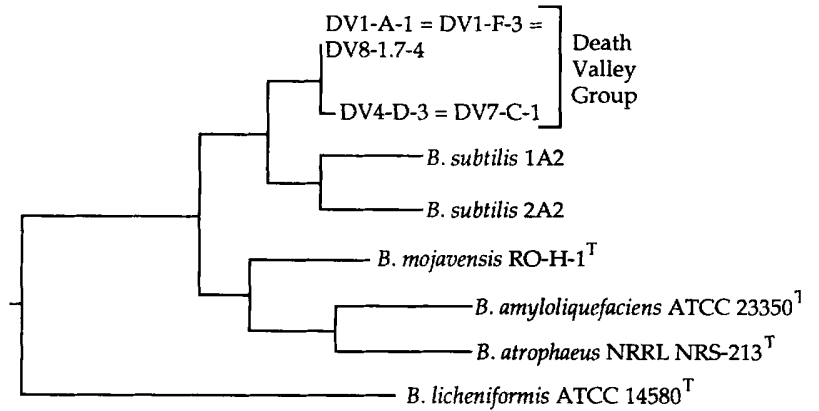

FIG. 1. Phylogeny based on restriction digestion of the $r p o B$, gyrA, and polC genes of 84 wild isolates and 2 laboratory strains of $B$. subtilis, 26 wild isolates of $B$. mojavensis, 14 wild isolates of $B$. licheniformis, and the type strains of $B$. amyloliquefaciens, B. atrophaeus, and B. licheniformis (phylogeny abridged from the study of Roberts and Cohan [15]). The wild isolates were collected from the Gobi Desert, the Sahara Desert, and three deserts in southwestern North America. The Death Valley group strains were found only in Death Valley in California. The hypothesis of monophyly of the Death Valley group has $98 \%$ bootstrap support (15). Strains $1 \mathrm{~A} 2$ and 2A2 represent the 168 and W23 subgroups of $B$. subtilis, respectively. Horizontal distances correspond to levels of sequence divergence.

other taxa could be studied only when Death Valley group strains were used as donors.

We investigated sexual isolation between the Death Valley group and $B$. subtilis by using $B$. subtilis $1 \mathrm{~A} 2$ as the recipient. In homogamic transformation experiments, $B$, subtilis $1 \mathrm{~A} 2$ was transformed at a frequency of $6.64 \times 10^{-3}$. The frequency of transformation was lower than this value when any of the five Death Valley group strains was used as the donor; strain 1A2 was transformed by Death Valley group strains at an average frequency of transformation of $4.24 \times 10^{-3}$ (Table 2). The average level of sexual isolation (ratio of homogamic transformation frequency to heterogamic transformation frequency) between the Death Valley group strains and B. subtilis 1A2 was 1.57 (i.e., the sexual isolation value [ $\log _{10}$ transformed] for the five Death Valley group strains was $0.20 \pm 0.05$ [mean \pm standard error]; $10^{0.20}=1.57$ ) (Table 2). The Death Valley group strains were not significantly heterogeneous in their levels of sexual isolation from the recipient in an analysis of
TABLE 2. Levels of sexual isolation when $B$. subtilis $1 \mathrm{~A} 2$ was the recipient and Death Valley group strains were the donors

\begin{tabular}{lcc}
\hline \multicolumn{1}{c}{ Donor strain } & $\begin{array}{c}\text { Transformation } \\
\text { frequency }^{a}\end{array}$ & $\begin{array}{c}\text { Sexual } \\
\text { isolation }^{c} \\
\text { value }^{b}\end{array}$ \\
\hline Death Valley group strains & & \\
DV1-A-1 & $-2.39 \pm 0.12$ & $0.22 \pm 0.13$ \\
DV1-F-3 & $-2.54 \pm 0.10$ & $0.36 \pm 0.15$ \\
DV4-D-3 & $-2.36 \pm 0.09$ & $0.18 \pm 0.16$ \\
DV7-C-1 & $-2.34 \pm 0.10$ & $0.16 \pm 0.17$ \\
DV8-1.7-4 & $-2.24 \pm 0.06$ & $0.06 \pm 0.15$ \\
Mean $^{c}$ & $-2.37 \pm 0.05$ & $0.20 \pm 0.05^{d}$ \\
\hline
\end{tabular}

${ }^{a}$ Transformation frequencies were $\log _{10}$ transformed as described by Cohan et al. (3). The values are the mean \pm standard error for each strain, based on five experimental trials.

${ }^{b}$ Factor by which the recipient's transformation frequency was reduced in heterogamic transformation compared with the frequency at which the recipient was transformed by its own Rif mutant's DNA. Sexual isolation values were $\log _{10}$ transformed. The values are the mean \pm standard error for each strain, based on five experimental trials. The recipient was transformed by its own $\mathrm{Rif}^{\mathrm{T}}$ mutant's DNA at an average $\log _{10}$-transformed frequency of $-2.18 \pm 0.14(=$ $\left.6.64 \times 10^{-3}\right)$ in five experimental trials.

c Mean \pm standard error for five Death Valley group strains.

${ }^{d} P<0.01$ as determined by a one-tailed $t$ test of the difference between the experimental value and zero.

variance $\left(F_{4,24}<1\right)$. The extents of sexual isolation between the Death Valley group strains and strain $1 \mathrm{~A} 2$, although modest, were highly significant $(t=4.09, P<0.01$; one-tailed $t$ test for the difference between the mean $\log _{10}$-transformed sexual isolation value, $0.20 \pm 0.05$, and zero). In contrast, previous results have shown that the recipient which we used, $B$. subtilis $1 \mathrm{~A} 2$, is not sexually isolated from $B$. subtilis strains; the $\log _{10^{-}}$ transformed values of sexual isolation between strain $1 \mathrm{~A} 2$ and other $B$. subtilis strains range from 0.02 to 0.10 , with a mean of $0.06 \pm 0.02$, which is not significantly different from zero (16).

DNA-DNA reassociation. Table 3 shows the levels of DNADNA reassociation between the Death Valley group strains and the type strains of the following taxa: $B$. amyloliquefaciens, $B$. atrophaeus, $B$. lentimorbus, B. licheniformis, B. mojavensis, $B$. popilliae, and $B$. subtilis. This list includes all of the species that are, according to $16 \mathrm{~S}$ RNA sequence data (1), at least as

TABLE 1. Bacillus strains compared in this study

\begin{tabular}{|c|c|c|}
\hline Strain & Source $^{a}$ & History \\
\hline \multicolumn{3}{|l|}{ Death Valley group strains ${ }^{b}$} \\
\hline DV1-A-1 (= NRRL B-14892) & 1 & Isolated from sand dune with mesquite tree, $36^{\circ} 39^{\prime} \mathrm{N}, 117^{\circ} 5^{\prime} \mathrm{W}$ \\
\hline DV1-F-3 $3^{\mathrm{T}}\left(=\text { NRRL B-14890 }{ }^{\mathrm{T}}\right)^{\mathrm{c}}$ & 1 & Isolated from sand dune with mesquite tree, $36^{\circ} 39^{\prime} \mathrm{N}, 117^{\circ} 5^{\prime} \mathrm{W}$ \\
\hline DV4-D-3 (= NRRL B-14893) & 1 & Isolated from alluvial fan with creosote bushes, $36^{\circ} 18^{\prime} \mathrm{N}, 116^{\circ} 54^{\prime} \mathrm{W}$ \\
\hline DV7-C-1 (= NRRL B-14894) & 1 & $\begin{array}{l}\text { Isolated from arroyo in alluvial fan with desert holly bushes, } 36^{\circ} 21^{\prime} \mathrm{N} \text {, } \\
116^{\circ} 51^{\prime} \mathrm{W}\end{array}$ \\
\hline DV8-1.7-4 (= NRRL B-14891) & 1 & Isolated from alluvial fan with desert holly bushes, $36^{\circ} 17^{\prime} \mathrm{N}, 116^{\circ} 54^{\prime} \mathrm{W}$ \\
\hline B. amyloliquefaciens NRRL B-14393 ${ }^{\mathrm{T}}\left(=\right.$ ATCC $\left.23350^{\mathrm{T}}\right)$ & 2 & L. L. Campbell strain F from J. Fukomoto, from soil \\
\hline B. atrophaeus NRRL NRS $-213^{\mathrm{T}}$ & 2 & N. R. Smith, "B. subtilis var. niger," from Colorado soil \\
\hline B. lentimorbus NRRL B-2522 ${ }^{\mathrm{T}}\left(=\right.$ ATCC $\left.14707^{\mathrm{T}}\right)$ & 2 & Isolated from diseased Japanese beetle grub \\
\hline B. licheniformis NRRL NRS- $1264^{\mathrm{T}}\left(=\right.$ ATCC $\left.14580^{\mathrm{T}}\right)$ & 2 & R. E. Gordon from T. Gibson 46 \\
\hline B. mojavensis NRRL B-14698 & 2 & Isolated by F. M. Cohan from soil, Mojave Desert, Calif. \\
\hline B. popilliae NRRL B-2309 ${ }^{\mathrm{T}}\left(=\right.$ ATCC $\left.14706^{\mathrm{T}}\right)$ & 2 & Isolated from commercial anti-Japanese beetle spore dust \\
\hline \multicolumn{3}{|l|}{ B. subtilis strains } \\
\hline NRRL NRS- $744^{\mathrm{T}}\left(=\right.$ ATCC $\left.6051^{\mathrm{T}}\right)$ & 2 & \\
\hline $1 \mathrm{~A} 2(=\mathrm{NRRL} \mathrm{B}-14819)$ & 3 & J. Lederberg \\
\hline
\end{tabular}

${ }^{a}$ 1, F. M. Cohan, Department of Biology, Wesleyan University, Middletown, Conn.; 2, L. K. Nakamura, National Center for Agricultural Utilization Research, Peoria, III.; 3, D. R. Zeigler and D. H. Dean, Bacillus Genetic Stock Center, Ohio State University, Columbus.

${ }^{b}$ All Death Valley group strains have been deposited in the Agricultural Research Service Culture Collection at the National Center for Agricultural Utilization Research, Peoria, Ill.

${ }^{c} \mathrm{~T}=$ type strain. 
TABLE 3. Levels of DNA-DNA reassociation between genomes of isolates

\begin{tabular}{|c|c|c|c|c|c|}
\hline \multirow[b]{2}{*}{ Strain } & \multicolumn{5}{|c|}{$\%$ DNA-DNA reassociation with $^{a}:$} \\
\hline & $\begin{array}{c}\text { Strain } \\
\text { DV1-A-1 }\end{array}$ & $\begin{array}{c}\text { Strain } \\
\text { DV1-F-3 }{ }^{\mathrm{T}}\end{array}$ & $\begin{array}{c}\text { Strain } \\
\text { DV4-D-3 }\end{array}$ & $\begin{array}{c}\text { Strain } \\
\text { DV7-C-1 }\end{array}$ & $\begin{array}{c}\text { Strain } \\
\text { DV8-1.7-4 }\end{array}$ \\
\hline DV1-A-1 & $(100)^{b}$ & & & & \\
\hline DV $1-F-3^{T}$ & 97.5 & $(100)$ & & & \\
\hline DV4-D-3 & 100 & 85.6 & $(100)$ & & \\
\hline DV7-C-1 & 100 & 100 & 100 & $(100)$ & \\
\hline DV8-1.7-4 & 100 & 98.8 & 94.3 & 100 & $(100)$ \\
\hline B. amyloliquefaciens NRRL B-14393 ${ }^{\mathrm{T}}$ & 22.4 & 13.7 & 24.6 & 10.8 & 20.8 \\
\hline B. atrophaeus NRRL NRS- $213^{\mathrm{T}}$ & 16.0 & 16.6 & 13.7 & 17.1 & 15.6 \\
\hline B. lentimorbus NRRL B- $2522^{\mathrm{T}}$ & 30.0 & 23.1 & 19.9 & 25.3 & 29.4 \\
\hline B. licheniformis NRRL NRS- $1264^{\mathrm{T}}$ & 29.5 & 16.7 & 10.2 & 15.0 & 26.7 \\
\hline B. mojavensis NRRL B-14698 & 32.3 & 23.3 & 23.4 & 18.8 & 22.3 \\
\hline B. popilliae NRRL B- $2309^{\mathrm{T}}$ & 26.9 & 11.4 & 33.0 & 13.8 & 21.1 \\
\hline B. subtilis NRRL NRS- $744^{\mathrm{T}}$ & 25.9 & 22.1 & 35.4 & 13.1 & 33.0 \\
\hline
\end{tabular}

${ }^{a}$ The reassociation values are the averages of two determinations; the maximum difference found between determinations was $7 \%$.

${ }^{b}$ The values in parentheses indicate that, by definition, the reassociation value was $100 \%$.

closely related to $B$. subtilis as $B$. licheniformis is. The strains of the Death Valley group strains exhibited high levels of DNADNA reassociation with one another $(85.6$ to $100 \%)$ but much lower levels of reassociation (10.2 to $35.4 \%$ ) with the type strains of the other taxa.

Phenotypic characterization. The Death Valley group strains could not be distinguished from $B$. subtilis or $B$. mojavensis by any of the physiological, morphological, or metabolic characteristics shown in Table 4, and very few of these characteristics distinguished these isolates from the other species. A positive oxidase test was the only trait that differentiated the Death
Valley group strains from $B$. atrophaeus. The inability to ferment lactose differentiated the Death Valley group strains from $B$. amyloliquefaciens. Utilization of propionate, anaerobic growth, and a $\mathrm{G}+\mathrm{C}$ content of $46 \mathrm{~mol} \%$ separated the Death Valley group strains from $B$. licheniformis. Table 4 shows that 15 traits distinguished the Death Valley group strains from $B$. lentimorbus and $B$. popilliae. Other distinguishing characteristics of $B$. lentimorbus and $B$. popilliae are insecticidal activity, formation of swollen sporangia, and an inability to grow in nutrient broth (2).

All of the organisms listed in Table 4 (except B. lentimorbus

TABLE 4. Phenotypic comparison of the Death Valley group strains, B. subtilis, B. atrophaeus, B. mojavensis, B. amyloliquefaciens, $B$. licheniformis, $B$. lentimorbus, and $B$. popilliae

\begin{tabular}{|c|c|c|c|c|c|c|c|c|}
\hline Characteristic & $\begin{array}{l}\text { Death Valley } \\
\text { group strains }\end{array}$ & $\begin{array}{l}\text { B. subtilis } \\
\text { NRRL } \\
\text { NRS-744 }\end{array}$ & $\begin{array}{l}\text { B. atrophaeus } \\
\text { NRRL } \\
{\text { NRS- } 213^{\mathrm{T}}}\end{array}$ & $\begin{array}{l}\text { B. mojavensis } \\
\text { NRRL } \\
\text { B-14698 }\end{array}$ & $\begin{array}{l}\text { B. amylolique- } \\
\text { faciens NRRL } \\
\text { B-14393 }\end{array}$ & $\begin{array}{l}\text { B. licheniformis } \\
\text { NRRL } \\
\text { NRS- } 1264^{\mathrm{T}}\end{array}$ & $\begin{array}{l}\text { B. lenti- } \\
\text { morbus }^{a}\end{array}$ & B. popilliae \\
\hline Anaerobic growth & $-{ }^{b}$ & - & - & - & - & + & + & + \\
\hline Growth at $\mathrm{pH} 5.7$ & + & + & + & + & + & + & - & - \\
\hline \multicolumn{9}{|l|}{ Growth in the presence of: } \\
\hline $3 \% \mathrm{NaCl}$ & + & + & + & + & + & + & - & ND \\
\hline $5 \% \mathrm{NaCl}$ & + & + & + & + & + & + & - & - \\
\hline $7 \% \mathrm{NaCl}$ & + & + & + & + & + & + & - & - \\
\hline $10 \% \mathrm{NaCl}$ & + & + & + & + & + & + & - & - \\
\hline 0.001\% Lysozyme & - & - & - & - & - & - & + & + \\
\hline Catalase activity & + & + & + & + & + & + & - & - \\
\hline Oxidase activity & + & + & - & + & + & + & ND & ND \\
\hline Acetylmethylcarbinol & + & + & + & + & + & + & - & - \\
\hline Maximum growth temp $\left({ }^{\circ} \mathrm{C}\right)$ & 50 & 50 & 50 & 50 & 50 & 55 & 35 & 35 \\
\hline Minimum growth temp $\left({ }^{\circ} \mathrm{C}\right)$ & 10 & 10 & 10 & 10 & 10 & 15 & 20 & 20 \\
\hline \multicolumn{9}{|l|}{ Acid produced from: } \\
\hline Glucose & + & + & + & + & + & + & + & + \\
\hline Arabinose & + & + & + & + & + & + & - & - \\
\hline Xylose & + & + & + & + & + & + & - & - \\
\hline Mannitol & + & + & + & + & + & + & - & - \\
\hline Lactose & - & - & - & - & + & - & ND & ND \\
\hline Starch hydrolysis & + & + & + & + & + & + & - & - \\
\hline \multicolumn{9}{|l|}{ Utilization of: } \\
\hline Citrate & + & + & + & + & + & + & - & _- \\
\hline Propionate & - & - & - & - & - & + & - & - \\
\hline Nitrate reduced to nitrite & + & + & + & + & + & + & - & - \\
\hline Casein decomposition & + & + & + & + & + & + & - & - \\
\hline Tween 80 decomposition & + & $\mathrm{w}$ & + & + & ND & ND & ND & ND \\
\hline $\mathrm{G}+\mathrm{C}$ content $(\mathrm{mol} \%)$ & 43 & 43 & 42 & 43 & 43 & 46 & 38 & 41 \\
\hline
\end{tabular}

${ }^{a}$ Data from reference 2 .

$b-$, negative reaction; + , positive reaction; $w$, weak reaction; ND, not determined. 
TABLE 5. Cellular fatty acid compositions of the Death Valley group strains, B. amyloliquefaciens, B. atrophaeus, B. licheniformis, B. mojavensis, and B. subtilis

\begin{tabular}{|c|c|c|c|c|c|c|c|}
\hline \multirow[b]{2}{*}{ Fatty acid } & \multirow[b]{2}{*}{$\begin{array}{l}\text { Fatty } \\
\text { acid no. }\end{array}$} & \multicolumn{6}{|c|}{$\%$ in: } \\
\hline & & $\begin{array}{l}\text { Death Valley } \\
\text { group strains } \\
\quad(n=5)\end{array}$ & $\begin{array}{l}\text { B. amyloliquefaciens } \\
\qquad(n=3)^{a}\end{array}$ & $\begin{array}{l}\text { B. atrophaeus } \\
(n=5)^{a}\end{array}$ & $\begin{array}{l}\text { B. licheniformis } \\
(n=5)^{a}\end{array}$ & $\begin{array}{l}\text { B. mojavensis } \\
(n=22)^{a}\end{array}$ & $\begin{array}{l}\text { B. subtilis } \\
(n=5)^{a}\end{array}$ \\
\hline $14: 0$ iso & 1 & $1.07 \pm 0.02^{b}$ & $2.46 \pm 0.69^{c}$ & $1.44 \pm 0.14$ & $1.31 \pm 0.44$ & $0.98 \pm 0.24$ & $1.13 \pm 0.24$ \\
\hline $15: 0$ iso & 2 & $24.60 \pm 1.37$ & $30.50 \pm 5.93$ & $15.02 \pm 2.55$ & $28.87 \pm 2.69$ & $22.33 \pm 3.19$ & $29.27 \pm 4.64$ \\
\hline $15: 0$ anteiso & 3 & $37.5 \pm 0.77$ & $36.48 \pm 7.88$ & $51.36 \pm 1.08$ & $37.75 \pm 2.58$ & $42.51 \pm 1.67$ & $40.19 \pm 3.98$ \\
\hline $16: 1$ cis 9 alcohol & 4 & $0.45 \pm 0.04$ & $0.62 \pm 0.87$ & $1.16 \pm 0.20$ & $0.91 \pm 0.44$ & $0.69 \pm 0.29$ & $0.23 \pm 0.35$ \\
\hline $16: 0$ iso & 5 & $4.06 \pm 0.39$ & $4.40 \pm 0.75$ & $3.10 \pm 0.61$ & $4.42 \pm 1.72$ & $2.56 \pm 0.41$ & $2.36 \pm 0.34$ \\
\hline $16: 1$ cis 5 & 6 & $0.64 \pm 0.03$ & $2.14 \pm 0.11$ & $1.72 \pm 0.11$ & $1.53 \pm 0.24$ & $1.74 \pm 0.40$ & $1.52 \pm 0.45$ \\
\hline $16: 0$ & 7 & $2.71 \pm 0.42$ & $4.52 \pm 0.50$ & $1.99 \pm 0.32$ & $3.91 \pm 0.53$ & $2.05 \pm 0.41$ & $3.14 \pm 0.40$ \\
\hline $17: 1$ cis 7 iso & 8 & $1.55 \pm 0.40$ & $1.67 \pm 0.61$ & $1.99 \pm 0.44$ & $1.23 \pm 0.33$ & $3.45 \pm 0.62$ & $1.72 \pm 0.42$ \\
\hline $17: 0$ iso & 9 & $14.43 \pm 0.66$ & $9.01 \pm 1.34$ & $4.97 \pm 0.59$ & $6.99 \pm 1.06$ & $8.92 \pm 1.46$ & $9.59 \pm 1.56$ \\
\hline 17:0 anteiso & 10 & $12.07 \pm 1.09$ & $7.06 \pm 2.69$ & $14.83 \pm 2.36$ & $11.30 \pm 0.93$ & $12.53 \pm 1.89$ & $9.38 \pm 0.95$ \\
\hline
\end{tabular}

\footnotetext{
${ }^{a}$ Data from reference 16.

${ }^{b}$ Mean \pm standard deviation.

${ }^{c}$ The values in boldface type were significantly different $(P<0.05)$ from the Death Valley group values, as determined by $t$ tests after we corrected for multiple comparisons by the sequential Bonferroni method.
}

and $B$. popilliae, which were not tested) fermented cellobiose, fructose, galactose, maltose, mannose, raffinose, L-rhamnose, ribose, salicin, sorbitol, sucrose, and trehalose; melibiose was not fermented by these organisms (data not shown).

The principal fatty acids found in the Death Valley group strains, $B$. amyloliquefaciens, $B$. atrophaeus, $B$. licheniformis, $B$. mojavensis, and $B$. subtilis included 12-methyltridecanoic (14:0 iso), 13-methyltetradecanoic (15:0 iso), 12-methyltetradecanoic (15:0 anteiso), 14-methylpentadecanoic (16:0 iso), $n$ hexadecanoic (16:0), 15-methylpentadecanoic (17:0 iso), 14methylhexadecanoic (17:0 anteiso), cis-5-hexadecanoic (16:1 cis5), and cis-15-methyl-17-hexadecanoic (17:1 cis7 iso) acids. cis-9-Hexadecenol was also found.

Significant differences in the levels of several fatty acids could be used to differentiate the Death Valley group strains from other taxa (Table 5). Specifically, differences in the levels of 16:0 iso, 16:1 cis5, 17:0 iso, and 17:0 anteiso distinguished the Death Valley group strains from $B$. subtilis; differences in the levels of 5 of the 10 fatty acids found distinguished the Death Valley group strains from $B$. amyloliquefaciens; $B$. atrophaeus and $B$. mojavensis could be distinguished from the Death Valley group strains by significant differences in 6 of the 10 fatty acids found (not the same ones); and the Death Valley group strains and $B$. licheniformis could be distinguished by significant differences in two fatty acids.

We performed a principal-component analysis (17) on the fatty acid phenotypes to determine whether the Death Valley group strains form a phenotypic cluster that is distinct from other taxa. As shown in Fig. 2, the first three principal components of fatty acid variation distinguished the Death Valley group strains as members of a separate phenotypic cluster.

\section{DISCUSSION}

A previous survey (15) of sequence diversity in close relatives of B. subtilis showed that the Death Valley group Bacillus strains form a distinct, monophyletic group that is most closely related to $B$. subtilis (Fig. 1). This previous study showed that the Death Valley group can be distinguished from other taxa on the basis of the results of restriction digestion analyses of the $g y r A$, polC, and $r p o B$ genes.

In this study we found that in principle, the Death Valley group can be distinguished from its closest relative, $B$. subtilis, on the basis of weak sexual isolation in transformation exper-
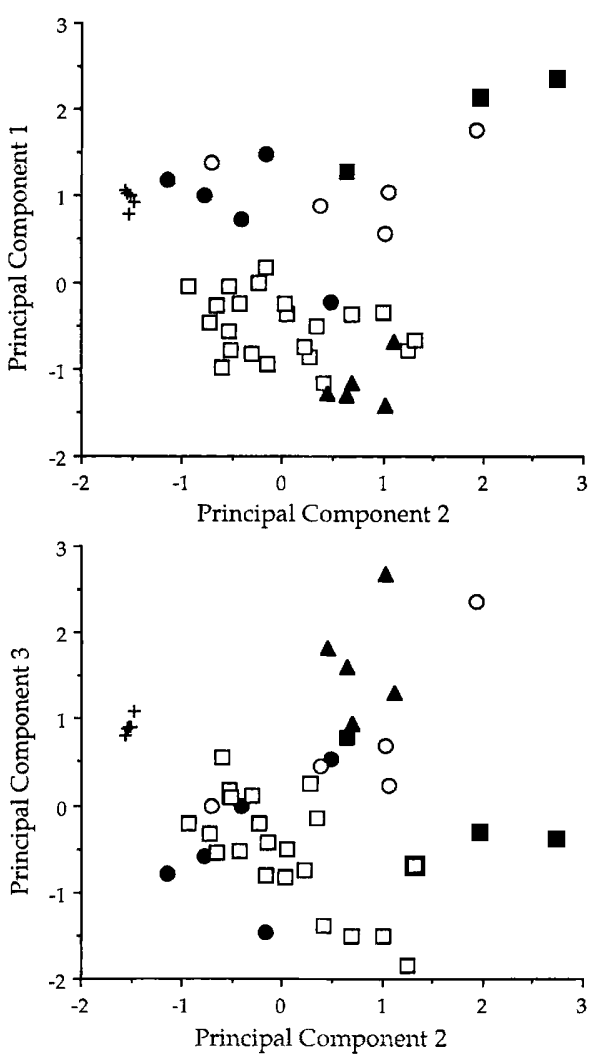

FIG. 2. Principal-component analysis based on the 10 fatty acids in Table 5 . The Death Valley group is a distinct phenotypic cluster when pairs of the first three principal components are used. Symbols: +, Death Valley group strains; $\mathbf{Q}$, $B$. subtilis strains; $\bigcirc, B$. licheniformis strains; $\square, B$. amyloliquefaciens strains; $\square, B$. mojavensis strains; $\boldsymbol{\Delta}, B$. atrophaeus strains. The eigenvalues for the first three principal components are $3.54,2.47$, and 2.09 , respectively. The first three principal components $\left(\mathrm{PC}_{i}\right.$ for $\left.i=1,3\right)$ are the following functions of fatty acid phenotypes: $\mathrm{PC}_{1}=0.20 \mathrm{FA}_{1}+0.40 \mathrm{FA}_{2}-0.42 \mathrm{FA}_{3}-0.24 \mathrm{FA}_{4}+0.28 \mathrm{FA}_{5}-$ $0.15 \mathrm{FA}_{6}+0.44 \mathrm{FA}_{7}-0.34 \mathrm{FA}_{8}+0.24 \mathrm{FA}_{9}-0.31 \mathrm{FA}_{10} ; \mathrm{PC}_{2}=0.50 \mathrm{FA}_{1}+$ $0.07 \mathrm{FA}_{2}+0.07 \mathrm{FA}_{3}+0.44 \mathrm{FA}_{4}+0.21 \mathrm{FA}_{5}+0.47 \mathrm{FA}_{6}+0.15 \mathrm{FA}_{7}+0.00 \mathrm{FA}_{8}$ $-0.47 \mathrm{FA}_{9}-0.22 \mathrm{FA}_{10}$; and $\mathrm{PC}_{3}=0.16 \mathrm{FA}_{1}-0.41 \mathrm{FA}_{2}+0.25 \mathrm{FA}_{3}+0.08$ $\mathrm{FA}_{4}+0.46 \mathrm{FA}_{5}-0.31 \mathrm{FA}_{6}+0.20 \mathrm{FA}_{7}-0.43 \mathrm{FA}_{8}-0.03 \mathrm{FA}_{9}+0.45 \mathrm{FA}_{10}$, where $\mathrm{FA}_{i}$ is the percentage of the $i$ th fatty acid (see Table 5). Each principal component was standardized to have a mean of zero and variance equal to the corresponding eigenvalue. 
iments. Transformation of a $B$. subtilis recipient by the Death Valley group strains resulted in a mean sexual isolation value (ratio of homogamic to heterogamic transformation frequencies) of 1.57 ; this value corresponds to a $36 \%$ reduction in transformation compared with homogamic transformation.

Previous studies have shown that sexual isolation in Bacillus transformation experiments is largely determined by the extent of sequence divergence at the gene transformed and that sexual isolation is closely predicted as a log-linear function of sequence divergence $(14,21)$, as follows: $\log _{10}(\rho)=18.87 \pi-$ 0.23 , where $\pi$ is the donor-recipient sequence divergence value at the transformed gene $(r p o B)$ and $\rho$ is the sexual isolation value. While these previous studies did not include the Death Valley group strains, the observed sexual isolation between the Death Valley group strains and $B$. subtilis $(\rho=1.57)$ is reasonably close to the value predicted from this equation $(\rho=1.93)$, given $2.7 \%$ divergence at $r p o B(15,21)$. This close fit supports the hypothesis that sexual isolation between the Death Valley group and $B$. subtilis strains is caused by sequence divergence between these groups.

While the modest sexual isolation between the Death Valley group and $B$. subtilis appears to be real, the magnitude of isolation between these groups is probably not large enough for this trait to be used reliably as a diagnostic characteristic. This is in contrast to what is found with more divergent taxa, which exhibit greater levels of sexual isolation. For example, $B$. mojavensis was first discovered because its strains consistently showed sexual isolation from $B$. subtilis $(3,16)$.

The Death Valley group strains exhibit levels of DNA-DNA reassociation of less than $35 \%$ with the type strains of previously described Bacillus species, but the levels of intragroup reassociation are $85 \%$ or more. These data confirm the cohesiveness of the Death Valley group and establishes this group as a genetically distinct taxon.

The Death Valley group differs significantly from all of its closest relatives in whole-cell fatty acid composition. A principal-component analysis of fatty acid composition showed that the Death Valley group strains form a phenotypic cluster that is distinct from all related taxa (Fig. 2). Thus, fatty acid composition provides a phenotypic diagnostic characteristic for distinguishing the Death Valley group.

Although several physiological, morphological, and metabolic traits were considered in this study, at this time the Death Valley group can be distinguished phenotypically from $B$. subtilis only on the basis of whole-cell fatty acid composition. Thus, the Death Valley group fits a pattern found for other close relatives of $B$. subtilis; namely, close relatives of $B$. subtilis that can be distinguished on the basis of sequence divergence are generally distinguished by very few physiological, morphological, or metabolic characteristics $(3,5,7-9,11,12,14-16,19$, 20).

Description of Bacillus vallismortis sp. nov. Bacillus vallismortis (val.lis.mor' tis. L. n. vallis, valley; L. fem. n. mors, death; M. L. gen. fem. n. vallismortis, of Death Valley). Vegetative cells are bacilli that are 0.8 to $1.0 \mu \mathrm{m}$ wide by 2.0 to $4.0 \mu \mathrm{m}$ long (as determined by measurements obtained from photomicrographs) and occur singly and in short chains. Motile. Gram positive. Forms ellipsoidal spores centrally and paracentrally in unswollen sporangia.

Agar colonies are opaque, smooth, circular, entire, and 1.0 to $2.0 \mathrm{~mm}$ in diameter after incubation for 2 days at $28^{\circ} \mathrm{C}$.

Catalase and oxidase are produced. Aerobic. Acetylmethylcarbinol is produced. The $\mathrm{pH}$ in Voges-Proskauer broth after 2 days ranges from 5.4 to 5.7 . Nitrate is reduced to nitrite. Starch and casein are hydrolyzed. Citrate is utilized, but propionate is not utilized. Hydrogen sulfide, indole, and dihy- droxyacetone are not produced. Egg yolk lecithin and urea are not decomposed. Tween 80 is decomposed. The $\mathrm{pH}$ in litmus milk is alkaline; casein is digested.

Phenylalanine and tyrosine are not decomposed.

Acid but no gas is produced from L-arabinose, cellobiose, fructose, glucose, galactose, maltose, mannitol, mannose, Lrhamnose, ribose, salicin, sorbitol, sucrose, trehalose, and xylose. Lactose and melibiose are not fermented.

The optimum growth temperature ranges from 28 to $30^{\circ} \mathrm{C}$, the maximum growth temperature is about $50^{\circ} \mathrm{C}$, and the minimum growth temperature ranges from 5 to $10^{\circ} \mathrm{C}$. Growth occurs at $\mathrm{pH} 5.7$ and in the presence of $10 \% \mathrm{NaCl}$. Inhibited by $0.001 \%$ lysozyme.

The thermal denaturation temperature for DNA of the type strain is $86.9^{\circ} \mathrm{C}$, and the $\mathrm{G}+\mathrm{C}$ content determined from this value is $43 \mathrm{~mol} \%$.

The description given above is virtually identical to the descriptions of $B$. atrophaeus, $B$. mojavensis, and $B$. subtilis. $B$. vallismortis can be differentiated from these previously described species by DNA reassociation data, by data from restriction digestion analyses of selected genes, and by fatty acid analysis data.

Isolated from desert soil.

The type strain is strain DV1-F-3, which has been deposited in the Agricultural Research Service Culture Collection as strain NRRL B-14890.

\section{ACKNOWLEDGMENTS}

Soil from Death Valley National Monument was collected under permit A9015 issued by the U.S. National Park Service.

This research was supported by National Institutes of Health grant GM39501, U.S. Environmental Protection Agency grant R82-1388010, and research grants from Wesleyan University.

\section{REFERENCES}

1. Ash, C., J. A. E. Farrow, S. Wallbanks, and M. D. Collins. 1991. Phylogenetic heterogeneity of the genus Bacillus revealed by comparative analysis of small-subunit-ribosomal RNA sequences. Lett. Appl. Microbiol. 13:202-206.

2. Claus, D., and R. C. W. Berkeley. 1986. Genus Bacillus Cohn 1872, p. 1105-1139. In P. H. A. Sneath, N. S. Mair, M. E. Sharpe, and J. G. Holt (ed.), Bergey's manual of systematic bacteriology, vol. 2. Williams \& Wilkins, Baltimore.

3. Cohan, F. M., M. S. Roberts, and E. C. King. 1991. The potential for genetic exchange by transformation within a natural population of Bacillus subtilis. Evolution 45:1393-1421.

4. De Ley, J., H. Cattoir, and A. Reynaerts. 1970. The quantitative measurement of DNA hybridization from renaturation rates. Eur. J. Biochem. 12: $133-142$.

5. Dubnau, D., I. Smith, P. Morell, and J. Marmur. 1965. Gene conservation in Bacillus species. I. Conserved genetic and nucleic acid base sequence homologies. Proc. Natl. Acad. Sci. USA 54:491-498.

6. Gordon, R. E., W. C. Haynes, and C. H. Pang. 1973. The genus Bacillus. Agriculture Handbook no. 427. U.S. Department of Agriculture, Washington, D.C.

7. Harford, N., and M. Mergeay, 1973. Interspecific transformation of rifampicin resistance in the genus Bacillus. Mol. Gen. Genet. 120:151-155.

8. Harris-Warrick, R. M., and J. Lederberg. 1978. Interspecies transformation in Bacillus: sequence heterology as the major barrier. J. Bacteriol. 133:1237-1245.

9. Logan, N. A., and R. C. W. Berkeley. 1984. Identification of Bacillus strains using the API system. J. Gen. Microbiol. 130:1871-1882.

10. Mandel, M., and J. Marmur. 1968. Use of ultraviolet absorbance-temperature profile for determining the guanine plus cytosine content of DNA. Methods Enzymol. 12B:195-206.

11. Nakamura, L. K. 1987. Deoxyribonucleic acid relatedness of lactose-positive Bacillus subtilis strains and Bacillus amyloliquefaciens. Int. J. Syst. Bacteriol. 37:444-445.

12. Nakamura, L. K. 1989. Taxonomic relationship of black-pigmented Bacillus subtilis strains and a proposal for Bacillus atrophaeus sp. nov. Int. J. Syst. Bacteriol. 39:295-300.

13. Nakamura, L. K., and J. Swezey. 1983. Taxonomy of Bacillus circulans Jordon 1890: base composition and reassociation of deoxyribonucleic acid. Int. J. Syst. Bacteriol. 33:46-52.

14. Roberts, M. S., and F. M. Cohan. 1993. The effect of DNA sequence diver- 
gence on sexual isolation in Bacillus. Genetics 134:401-408.

15. Roberts, M. S., and F. M. Cohan. 1995 . Recombination and migration rates in natural populations of Bacillus subtilis and Bacillus mojavensis. Evolution 49:1081-1094

16. Roberts, M. S., L. K. Nakamura, and F. M. Cohan. 1994. Bacillus mojavensis sp. nov., distinguishable from Bacillus subtilis by sexual isolation, divergence in DNA sequence, and differences in fatty acid composition. Int. J. Syst. Bacteriol. 44:256-264.

17. SAS Institute, Inc. 1989. SAS/STAT user's guide, version 6, 4th ed., vol. 2. SAS Institute, Inc., Cary, N.C.
18. Sasser, M. 1990. Identification of bacteria by gas chromatography of cellular fatty acids. Technical Note 101. Microbial ID, Inc., Newark, Del.

19. te Riele, H. P. J., and G. Venema. 1982. Molecular fate of heterologous bacterial DNA in competent Bacillus subtilis. I. Processing of B. pumilus and B. licheniformis DNA in B. subtilis. Genetics 101:179-188.

20. Wilson, G. A., and F. E. Young. 1972. Intergenotic transformation of the Bacillus subtilis genospecies. J. Bacteriol. 111:705-716.

21. Zawadzki, P., M. S. Roberts, and F. M. Cohan. 1995. The log-linear relationship between sexual isolation and sequence divergence in Bacillus transformation is robust. Genetics 140:917-932. 